\title{
NUP98/NSD1 Fusion Protein
}

National Cancer Institute

\section{Source}

National Cancer Institute. NUP98/NSD1 Fusion Protein. NCI Thesaurus. Code C99435.

A fusion protein encoded by the NUP98/NSD1 fusion gene. This protein is comprised of the $\mathrm{N}$-terminal nucleoporin GLFG repeat domains of the nuclear pore complex protein Nup98-Nup96 protein fused to the C-terminal portion of the histone-lysine $\mathrm{N}$ -

methyltransferase, $\mathrm{H} 3$ lysine- 36 and $\mathrm{H} 4$ lysine-20 specific protein, including the SET and PHD domains. 